\title{
On-farm comparison of improved maize variety Manakamana-3 with Local Thulo Seto for grain yield and agronomic attributes at Dukuchhap, Lalitpur, Nepal
}

MN Paudel and R Khadka

Outreach Research Division, Khumaltar, NARC

\begin{abstract}
On-farm studies were carried out at Dukuchhap, (1100-1500 m), Lalitpur, an Outreach Research Site of Khumaltar complex during 2006-2007 full season maize growing (May-Sep). The study consisted of comparison among grain yield, and agronomic attributes between Manakamana-3, an improved OPV and Local Thulo Seto maize varieties. Field surveys were conducted to gather information on aforesaid attributes of these maize varieties. In 2006, data were recorded from 265 plants for Local Thulo Seto and 131 plants from different fields for Manakamana-3 while in 2007 they were recorded from 180 plants for both varieties. The result of the study revealed that both of these varieties were comparable for grain yield and ear length. However, combined analysis over years for plant and ear height, ear fill, and ear circumference showed a highly significant result. It was also recorded that plant height, ear height and ear filled remained dynamic between these varieties over years. Plant height of Local Thulo Seto was exceptionally tall up to $364 \mathrm{~cm}$ compared to Manakamana-3 which attained a plant height up to $241 \mathrm{~cm}$. The most important yield parameter of grain weight/ear was not affected due to years and varieties. Bivariate relationship among grain yield and agronomic attributes showed that grain weight/ear was highly correlated with ear length $\left(\mathrm{r}=0.73^{* *}\right)$, ear fill $\left(\mathrm{r}=0.75^{* *}\right)$, and ear circumference $(\mathrm{r}=0.63 * *)$. Ear height was not correlated with grain yield. It was also observed that plant height has a negative relationship with grain yield and ear attributes except for ear height which was positively correlated with plant height. Maize variety Thulo Seto is popular in Dukuchhap where area coverage of this variety is more than $80 \%$ in the locality. There is a serious limitation of this variety at Dukuchhap because of stalk lodging which was severe in 2006 as a result around $80 \%$ plants have the problem of stalk lodging. Farmers preferred this variety because it is resistant to early drought which is another problem for maize growing at Dukuchhap. Therefore, if we improve population of Thulo Seto in farmers' field and reduce plant height of this variety by way of population improvement there is no need of introducing new varieties of maize in immediate future at Dukuchhap and similar domain in Lalitpur.
\end{abstract}

Key words: Yield and agronomic attributes, bivariate relationship, interaction effect

\section{Introduction}

Agriculture in Nepal is the main stay of people. Population engaged in agriculture is $65.6 \%$ with the cultivated agriculture land of 30, 91,000 ha and the share of agriculture sector gross domestic product (GDP) at current price of 2007/08 is 32.6\% (MoAC 2007/08). Growth rate of agriculture sector during $2007 / 08$ was $2.13 \%$ while for non-agriculture sector it was $4.81 \%$ with the total GDP growth rate of $3.80 \%$ during the same period in the country. On the other hand, population growth rate in the same fiscal year was $2.25 \%$, a growth rate higher than agriculture growth rate by $0.02 \%$. It clearly shows that agriculture growth is trailing behind population growth in the country. Therefore, agriculture should get high priority to feed the burgeoning population in Nepal. There was a negative food balance of 133000 metric ton during 2008/09 where as food requirement was 5293000 metric ton in the country (MoAC, 2009). During the year 2008/09 the production of major staple of rice, maize, wheat, and millet was $4524000 \mathrm{mt}, 1391000 \mathrm{mt}, 1344000 \mathrm{mt}$ with the per hectare productivity of $2.9 \mathrm{mt}, 2.206 \mathrm{mt}$, and $1.93 \mathrm{mt}$, 
respectively. In Nepal, maize occupies second position of most important staple after rice in area and production while wheat trails behind maize (MoAC, 2009). Maize represents $27.5 \%$ of total agriculture land, however, for hills and mountain it is the first staple that covers $80.5 \%$ of the total maize area. In Nepal, productivity of major cereals is less than those of other countries of South and Southeast Asia. Theoretically, Nepal has been putting priority for agriculture almost in all five year plans after mid fifties whereas in practice agriculture has been put in low priority.

The impact of improved technologies to increase per unit productivity has a key role to play. Aside from generating technologies with respect to husbandry practices, plant protection, post harvest, and value chain of crop, 15 improved maize varieties have been released in Nepal since 1965 to date (NARC, 2007). Despite the glut of improved varieties, very few of them have been disseminated to farmers' filed. Potential productivity of those improved varieties is remarkably higher than the present national average. There is a big gap in maize productivity between yield obtained in research stations and farmers' filed. One of the reasons of such yield gap is lack of adoption of improved technologies in massive scale. In other words, there is no tailoring of appropriate technology need and technology development. After agrotechnologies are generated there are series of intermediaries that help bring technologies to the end users. In present context, there is no functional coordination among technology generator, disseminator, and end users. End users are confused as to who is responsible for solving on-the -spot problems related to complete packages of technology because farmers are least concerned about who are those so called technology contractor involved to agriculture. Improved varieties are one of the important technologies that can bring a positive change for increasing productivity of crops. Of so many improved technologies recommended for farmers why only have a handful of such technologies been adopted by them. This is a serious question and needs to be answered honestly. During 2006-2007 maize growing seasons, an improved open pollinated variety (OPV) of maize Manakamana-3 was compared with popular local variety Thulo Seto with an objective why farmers are reluctant to use improved OPV in the locality. In line with this idea, comparison of improved maize variety Manakaman-3 and local variety Thulo Seto at Dukuchhap, 1100-1500m, about $15 \mathrm{~km}$ away from Khumaltar complex, was carried out under farmers' management condition in maize growing season (May to September). Findings of the study could be delineated to similar agro-climatic domains across Nepal.

\section{Methodology}

During 2006-2007 maize growing seasons (May-Sep), some foundation seed of Manakamana-3, an improved OPV of maize, was given to farmers at Dukuchhap for seed multiplication purpose. Seed was the only input given to farmers and crop was managed by growers in a way local varieties are grown by them in the locality. For Manakamana-3 data were recorded from different seed multiplication plots whereas for Local Thulo Seto data were collected from different farmers' fields across Dukuchhap in similar conditions where Manakamana-3 was grown. In both years, samples were randomly chosen from the seed multiplication area for recording grain yield and agronomic related attributes. Sampling area was $2.06 \mathrm{~m}^{2}$ when maize was planted in $75 \mathrm{~cm}$ row and $25 \mathrm{~cm}$ plant spacing. However, farmers do not strictly follow appropriate spacing for maize planting. Eleven plants were recorded per sampling for collecting individual ear traits such as plant and ear height, ear length, ear fill, ear circumference, and grain weight/ear. In 2006, data were recorded from 265 plants for Local Thulo Seto and 131 plants for Manakamana-3 while in 2007 they were recorded from 180 plants for both varieties. Grain yield obtained from $2.06 \mathrm{~m}^{2}$ was adjusted to $15 \%$ moisture content (MC) and converted into hectare basis. Similarly 
grain weight per ear was also adjusted to $15 \% \mathrm{MC}$ and $80 \%$ shelling recovery after dehusking and weighing ear individually. Grain yield calculation was done by using the following formula:

Grain yield $(\mathrm{kg} / \mathrm{ha})$ at $15 \%$ moisture content $(\mathrm{MC})=$ Field weight $(\mathrm{kg}) * 10000 *(100-\mathrm{MC}) * 0.8 / \mathrm{Net}$ harvested area*85.

Where, shelling recovery of field weight is assumed $80 \%$ and moisture content at $15 \%$ to all the treatments.

Means were separated by ANOVA while bivariate comparison was done by Pearson Correlation for interpreting data. Data analysis was done by using IRRI Stat version 4.5 software packages.

\section{Results and discussion}

\section{Grain yield and agronomic attributes}

Combined ANOVA for plant and ear height, ear fill, and ear circumference were highly significant between varieties while ear length, grain weight/ ear and grain yield were comparable between them (Table 1). This explains that having comparable grain yield, there are still variations in some of the yield components between these varieties.

Table 1. Combined ANOVA for grain yield and agronomic attributes as affected by maize variety (Local Thulo Seto and Manakamana-3) during 2006-2007 at farmers' field, Dukuchhap

\begin{tabular}{lccccc}
\hline \multicolumn{1}{c}{ Attribute } & Treatment MS & DF & Residual MS & DF & F Probability \\
\hline Plant height & $0.13464 \mathrm{E}+07$ & 1 & 4362.2 & 754 & 0.000 \\
Ear height & $0.27981 \mathrm{E}+06$ & 1 & 1141.0 & 754 & 0.000 \\
Ear length & 17.524 & 1 & 8.8775 & 754 & 0.156 \\
Ear fill & 127.45 & 1 & 11.862 & 754 & 0.001 \\
Ear circumference & 10.122 & 1 & 1.7037 & 754 & 0.014 \\
Grain weight/ear & 12227.0 & 1 & 3548.9 & 754 & 0.06 \\
Grain yield & $0.31830 \mathrm{E}+06$ & 1 & $0.83341 \mathrm{E}+06$ & 64 & 0.546 \\
\hline
\end{tabular}

Similarly, a combined ANOVA for plant and ear height and ear filled was highly significant whereas ANOVA for ear length, ear circumference and grain yield was not significant between varieties over years (Table 2). There is a marked difference of grain yield and agronomic attributes of maize at the testing site. However, the data revealed that grain weight/ear and grain yield was neither affected by varieties nor years in the study.

Table 2. Combined ANOVA for grain yield and agronomic attributes as affected by year (2006 and 2007) for maize variety (Local Thulo Seto and Manakamana-3) at farmers' field, Dukuchhap

\begin{tabular}{lccccc}
\hline \multicolumn{1}{c}{ Attribute } & Treatment MS & DF & Residual MS & DF & F probability \\
\hline Plant height & $0.81318 \mathrm{E}+06$ & 1 & 5069.4 & 754 & 0.000 \\
Ear height & 14508.0 & 1 & 1492.8 & 754 & 0.002 \\
Ear length & 21.987 & 1 & 8.8716 & 754 & 0.112 \\
Ear fill & 72.068 & 1 & 11.936 & 754 & 0.014 \\
Ear circumference & 1.1195 & 1 & 1.7156 & 754 & 0.425 \\
Grain weight/ear & 1762.2 & 1 & 3562.8 & 754 & 0.489 \\
Grain yield & 56154.0 & 1 & $0.83751 \mathrm{E}+06$ & 64 & 0.792 \\
\hline
\end{tabular}

There was a significant effect for plant height, ear height and ear fill due to interaction between variety $\mathrm{x}$ year, however, their effect for ear length, ear circumference, grain weight, and grain yield were not affected due to the interaction between variety $\mathrm{x}$ year (Table 3 ). Interaction between year $\mathrm{x}$ variety was similar to that of component effect of variety and year to these traits in question (Table 1 and 2). 
Table 3. Combined ANOVA for grain yield and agronomic attributes as affected by interaction between year (2006 - 2007) $x$ varieties (Local Thulo Seto and Manakamana-3) at farmers' field, Dukuchhap

\begin{tabular}{lccccc}
\hline \multicolumn{1}{c}{ Attributes } & Treatment MS & DF & Residual MS & DF & F probability \\
\hline Plant height & $0.73156 \mathrm{E}+06$ & 3 & 3245.8 & 752 & 0.000 \\
Ear height & $0.10610 \mathrm{E}+06$ & 3 & 1092.8 & 752 & 0.000 \\
Ear length & 17.536 & 3 & 8.8545 & 752 & 0.114 \\
Ear fill & 80.480 & 3 & 11.742 & 752 & 0.000 \\
Ear circumference & 4.1498 & 3 & 1.7051 & 752 & 0.063 \\
Grain weight/ear & 4374.6 & 3 & 3557.2 & 752 & 0.297 \\
Grain yield & $0.26180 \mathrm{E}+06$ & 3 & $0.85276 \mathrm{E}+06$ & 62 & 0.822 \\
\hline
\end{tabular}

The mean data in both years revealed that plant height, ear height, and ear filled remained dynamic while other attributes were found static as a result of interaction between year x variety (Table 4).

Table 4. Mean table for grain yield and agronomic attributes as affected by interaction between varieties (Local Thulo Seto and Manakamana-3) x year (2006-2007) tested at farmers' field, Dukuchhap

\begin{tabular}{|c|c|c|c|c|c|c|c|c|}
\hline Variety & Year $^{\mathrm{a}}$ & $\begin{array}{c}\text { Grain } \\
\text { yield } \\
\text { (kg/ha) }\end{array}$ & $\begin{array}{c}\text { Grain } \\
\text { weight/ } \\
\text { ear }(g)\end{array}$ & $\begin{array}{c}\text { Plant } \\
\text { height } \\
(\mathbf{c m})\end{array}$ & $\begin{array}{c}\text { Ear } \\
\text { height } \\
(\mathrm{cm})\end{array}$ & $\begin{array}{c}\text { Ear } \\
\text { length } \\
(\mathrm{cm})\end{array}$ & $\begin{array}{c}\text { Ear fill } \\
(\mathrm{cm})\end{array}$ & $\begin{array}{c}\text { Ear } \\
\text { circumfe } \\
\text { rence } \\
(\mathbf{c m})\end{array}$ \\
\hline Local Thulo Seto & $1(n=265)$ & 4654 & 213 & 364.6 & 172.4 & 19.8 & 17.6 & 15.5 \\
\hline Local Thulo Seto & $2(n=180)$ & 4623 & 213 & 274.6 & 158.1 & 19.8 & 17.5 & 15.5 \\
\hline Manakamana-3 & $1(n=131)$ & 4643 & 219 & 242.7 & 118.9 & 19.7 & 17.7 & 15.7 \\
\hline Manakamana-3 & $2(n=180)$ & 4713 & 223 & 241.2 & 133.8 & 20.4 & 18.9 & 15.8 \\
\hline Grand mean & & 4658 & 217 & 292.3 & 150.5 & 19.9 & 17.9 & 15.6 \\
\hline $\mathrm{DF}$ & & 62 & 752 & 752 & 752 & 752 & 752 & 752 \\
\hline F probability & & 0.822 & 0.297 & 0.000 & 0.000 & 0.114 & 0.000 & 0.063 \\
\hline LSD $(\mathrm{P}<0.05)$ & & 189.875 & 12.042 & 11.503 & 6.674 & 0.600 & 0.691 & 0.263 \\
\hline $\mathrm{CV} \%$ & & 19.8 & 27.6 & 19.5 & 22.0 & 14.9 & 19.1 & 8.3 \\
\hline
\end{tabular}

${ }^{a}$ year 1 and 2 indicate year 2006 and 2007

\section{Relationship between grain yield and agronomic attributes}

Bivariate relationship among grain yield and agronomic attributes showed that grain weight/ear was highly correlated with ear length $\left(\mathrm{r}=0.73^{* *}\right)$, ear fill $\left(\mathrm{r}=0.746^{* *}\right)$, and ear circumference $\left(\mathrm{r}=0.628^{* *}\right)$ (Table 5). Ear height was not correlated with grain yield while plant height was weakly and negatively correlated with grain yield. It was also observed that plant height has a negative relationship with grain yield and ear attributes except ear height which has a significant positive relation with plant height (Table 5).

Table 5. Bivariate relationship among grain yield and agronomic attributes of Local Thulo Seto and Manakamana-3 improved maize varieties tested during 2006-2007 at Dukuchhap

\begin{tabular}{|c|c|c|c|c|c|c|c|}
\hline Attribute & $\begin{array}{c}\text { No. of } \\
\text { observati } \\
\text { ons }\end{array}$ & $\begin{array}{c}\text { Plant } \\
\text { height }\end{array}$ & $\begin{array}{c}\text { Ear } \\
\text { height }\end{array}$ & $\begin{array}{c}\text { Ear } \\
\text { length }\end{array}$ & Ear fill & $\begin{array}{c}\text { Ear } \\
\text { circumfer } \\
\text { ence }\end{array}$ & $\begin{array}{c}\text { Grain } \\
\text { weight/ear }\end{array}$ \\
\hline Plant height & 756 & & & & & & \\
\hline Ear height & 756 & $0.644(* *)$ & & & & & \\
\hline Ear length & 756 & -0.024 & 0.007 & & & & \\
\hline Ear fill & 756 & -0.066 & -0.014 & $0.827(* *)$ & & & \\
\hline Ear circumference & 756 & -0.030 & 0.003 & $0.336(* *)$ & $0.278(* *)$ & & \\
\hline Grain weight/ear & 756 & -0.029 & 0.011 & $0.725(* *)$ & $0.746(* *)$ & $0.628(* *)$ & \\
\hline Grain yield & 66 & -0.033 & 0.063 & $0.366(* *)$ & $0.282(*)$ & $0.253(*)$ & $0.358(* *)$ \\
\hline
\end{tabular}


In a study done by Paudel et al (2001) it was reported that maize variety Farmer's Local which produced a grain yield of $4.75 \mathrm{t} / \mathrm{ha}$ was comparable with Ganesh-1, an improved OPV (4.77 t/ha) at high hill site $(2200 \mathrm{~m})$ of Dhankuta in the eastern Nepal. This suggests that contaminated improved varieties of maize are considered as local varieties by farmers when such varieties are well adopted in particular domains where improved varieties were introduced few years back in these localities. Technologies especially improved varieties should be introduced in sites as per the demand of farmers. In Nepal in most of the cases, technologies are introduced without testing and verifying in a particular locality. Instead of this, technologies should be introduced in ground reality by testing them in particular domains. Researchers and extension personnel should take a positive feedback from farmers why new technologies are not accepted by them despite the claims that introduced technologies outperform existing ones.

Although farmers reported that Thulo Seto is a native variety at Dukuchhap. Yield and agronomic attributes of Manakamana-3 and Thulo Seto are comparable with each other. Hence, Thulo Seto could be a contaminated improved OPV in the locality introduced some years ago. The only problem for this variety is stalk lodging. This variety fits in prevailing cropping pattern of maize+ soybean-rapeseed (Baltori)-fallow, maize+ soybean-lentil or lentil+ rapeseed (Kalotori), maize/finger millet- fallow in upland condition at Dukuchhap. More than $80 \%$ of the area is covered by this variety at the testing site. Stalk lodging was so severe for this variety that Nepal Television (NTV) telecasted stalk lodging of maize at this site in one of its TV programs of agriculture news (NTV, August 2006). Thulo Seto is highly preferred in the area because of its white color, high grit recovery, a trait desired for porridge preparation, good for roasted corn, and high storability against corn weevil. At the same time, it is also resistant to early drought during vegetative phase which causes severe stress to crop one month after planting. If we improve population of Thulo Seto in farmers' field it is still a best variety for the area. For this purpose, population improvement of Thulo Seto should be done by reducing plant height. And it seems that there is no need of introducing new OPV varieties of maize in immediate future at Dukuchhap if we improve population of Thulo Seto. Agriculturalists should deeply consider farmers' perception with regard to technology intervention as to why new technologies are not easily perceived by the farmers. Generated technologies should match farmers' need as well as to fit into their cropping systems rather than altering whole technology.

\section{Conclusion}

Every new technology does not necessarily perform superior over prevailing one in certain agroecological domains. Farmers have a right not to accept imposed technologies without judiciously verifying in their systems for they have already innovated technologies to fit in their systems. There could be a modification of components of prevailing technologies without altering the adopted technologies for the domain in question. As in the case of Dukuchhap, plant height of Local Thulo Seto could be reduced without altering the whole variety because it is highly adopted in the locality and have many preferred attributes except stalk lodging. There is a thin line between technology adoption and rejection by farmers. Agriculturist should have a third eye why new technologies are not accepted easily by the farmers and new technologies should be tailored with farmers' need. 


\section{Reference}

MoAC (Ministry of agriculture and Cooperative). 2007. Statistical information on Nepalese agriculture 2005/06 (2062/63). APSD, Ministry of Agriculture and Cooperative, Katmandu, Nepal.

MoAC (Ministry of agriculture and Cooperative). 2009. Selected Indicators of Nepalese agriculture and Population. Statistical Information on Nepalese Agriculture, MoAC, Nepal.

NARC (Nepal Agricultural Research Council). 2007. Released and registered crop varieties in Nepal 1960-2007. Communication and Publication and Documentation, Division, NARC, Katmandu, Nepal.

Paudel, MN and TP Tiwari. 2001. Maize research at the agriculture research station, Dhankuta. ARSP Technical Paper No. 190, Pakhribas, Dhankuta, Nepal.

Paudel, MN, M Mishra, SP Ghimire, and TP Tiwari. 2001. On station varietal reports for summer crops at the Agricultural Research Station, Pakhribas, 1998/99 (2055/56). ARSP Working Paper No. 254, Pakhribas, Dhankuta, Nepal. 